\title{
Turističko i prostorno planiranje u Hrvatskoj i Jugoslaviji 1960-ih
}

\author{
JASENKA KRANJČEVIĆ \\ Institut za turizam \\ Zagreb, Hrvatska \\ jasenka.kranjcevic@iztzg.hr
}

U radu se na temelju tadašnje i recentne (domaće i strane) literature te prostornih planova istražuje međuodnos turističkoga i prostornoga planiranja u Hrvatskoj i Jugoslaviji 1960-ih. Analitičko-interpretativnom metodom proučava se međuodnos tadašnjega društveno-političkog sustava, politika prema turizmu i prostoru, društvenoga planiranja, tijela uprave, institucija specijaliziranih za planiranje, turističkoga prometa, izrađenih prostornih planova, intenziteta izgradnje smještajnih kapaciteta i dr. Zaključuje se da su turističko i prostorno planiranje međusobno bili povezani društvenim planovima razvoja, a rezultati djelovanja u prostoru ovisili su o brojnim, često i nepredvidivim društveno-političkim čimbenicima. U praksi je provedba planova dodatno usložnjena jer su oni često djelovali apstraktno i kontradiktorno u političkom sustavu koji je imao ograničenu sposobnost za provedbu kvalitetnih, ali ponekad i utopijskih ideja.

Ključne riječi: turističko planiranje; prostorno planiranje turizma; povijest prostornoga planiranja i turizma; 1960-e; Hrvatska; Jugoslavija

\section{Uvod}

Povijest turizma, turističke arhitekture i prostornoga planiranja Hrvatske i Jugoslavije iz razdoblja socijalizma (1945. - 1991.) u posljednja dva desetljeća više je predmet međunarodnih nego istraživanja u Hrvatskoj. ${ }^{1}$ Bez obzira na

1 Iako su razvoj turizma u socijalističkoj Jugoslaviji osmišljavali domaći stručnjaci, početkom ovoga stoljeća on je predmet međunarodnih istraživanja. Npr. Sveučilište u Grazu provelo je istraživanje Tourism and Leisure Cultures in Socialist Yugoslavia (2005. - 2008.), u kojem se među ostalim istraživao sociološki aspekt turizma, tj. transformacija od radnika do turista, kao i fenomen radničkih odmarališta. To znači da u inozemstvu vlada veći interes za povijest turizma iz razdoblja socijalizma nego u bivšim republikama, a današnjim državama. Vidi: BEYER, HAGEMANN, ZINGANEL, Holidays after the Fall; GRANDITS, TAYLOR, Yugoslavia's Sunny Side. U New Yorku je u muzeju MOMA 2018./2019. održana izložba Toward a Concrete Utopia: Architecture in Yugoslavia, 1948-1980, na kojoj je prezentirana i turistička arhitektura. - Od domaćih istraživača o povijesti turizma za vrijeme socijalizma ističu se radovi povjesničara Igora Dude (U potrazi za blagostanjem i dr.). 
dosadašnja međunarodna ili domaća istraživanja, nedostaju ona koja proučavaju međuodnos turističkoga i prostornoga planiranja utvrđivanjem usklađenosti sektorskih politika, tijela, institucija te planova razvoja na lokalnoj, regionalnoj, republičkoj i državnoj razini. U ovom radu istražuje se međuodnos turističkoga i prostornoga planiranja u Hrvatskoj i Jugoslaviji s naglaskom na 60-e godine prošloga stoljeća, tj. vrijeme kad je inozemni turistički promet dobio ozbiljan uzlet te kad je uslijedila intenzivna hotelska izgradnja. To je period rasta životnoga standarda, zbog čega si je sve veći broj pojedinaca i obitelji mogao priuštiti putovanja. ${ }^{2}$

Da bi se došlo do zaključka o međuodnosu turističkoga i prostornoga planiranja, analitičko-interpretativnom metodom obrađeni su: tadašnji društveno-politički sustav, sustav društvenoga planiranja, politike prema turizmu i prostoru, tijela uprave, specijalizirane institucije za planiranje, stručna udruženja, djelovanje političkih tijela, turistički promet, prostorni planovi turizma te intenzitet hotelske izgradnje.

Istraživanje o međuodnosu turističkoga i prostornoga planiranja ima neka ograničenja zbog nedostupnosti određenih podataka kao što su planirane i realizirane površine ugostiteljsko-turističke namjene, postotak realiziranih prostornih planova turizma, cijena turističkoga zemljišta itd.

Drugi svjetski rat nesumnjivo je zadao ozbiljan udarac turizmu i na globalnoj i na državnim razinama. Stoga je za vrijeme rata i na prostoru današnje Hrvatske (uključujući Istru i dijelove Dalmacije) turistički promet bio zanemariv. Turizam je potkraj rata dobio dodatni udarac jer je dio zgrada ugostiteljsko-turističke namjene uništen u bombardiranjima ${ }^{3}$, a u poraću devastiran raznašanjem opreme.

Za vrijeme rata sva graditeljsko-arhitektonska i prostorno planerska aktivnost bila je svedena na minimum. Dio arhitekata (većinom mladih) iz Hrvatske, posebno oni koji su djelovali u ilegali ${ }^{4}$, na različite je načine propitivao i izražavao nove stavove o urbanizmu, arhitekturi i obnovi. ${ }^{5}$

2 Nakon Drugoga svjetskog rata turizam je na globalnoj razini doživio vrtoglavi uspon, što je posljedica primjene tehnologije u razvoju prometa, graditeljstva, komunikacija, medicine itd., kao i pojave viška slobodnoga vremena.

3 DUMBOVIĆ BILUŠIĆ, JAKAŠA BORIĆ, KRANJČEVIĆ, „Hotelski sklop otoka Veliki Brijun; Urbanističko arhitektonska geneza", 354-369. Neki hoteli stradali su prilikom savezničkoga bombardiranja, primjerice Neptun na Brijunima 1945., a neki su devastirani raznašanjem opreme, npr. hotelski sklop Kupari kod Dubrovnika, hotel Alhambra na Lošinju.

Arhitekti i drugi „kulturni radnici” 1943. i 1944. sudjelovali su na stručnim skupovima (Topusko, Hvar, Šibenik) s ciljem unaprjeđenja urbanizma, graditeljstva i arhitekture. - Za organiziranje građevinske operative na Visu je 1944. organiziran Odbor za obnovu naselja, čiji je zadatak bio pripremiti sve one aktivnosti koje bi po završetku rata osigurale obnovu razrušenih naselja.

Većina mladih arhitekata bila je pod utjecajem moderne funkcionalističke arhitekture oblikovane kroz međunarodnu organizaciju arhitekata CIAM (fran. Congrès internationaux d'architecture moderne), osnovanu 1928. u La Sarrazu (Švicarska). CIAM je promicao načela moderne arhitekture, a u oblikovanju zgrada i urbanističkom planiranju vidjeli su ekonomski i politički potencijal, što su i artikulirali 1933. na kongresu u Ateni u tzv. Atenskoj povelji (objavljenoj tek 1943.). 


\section{Novo doba, novo društvo}

Nakon Drugoga svjetskog rata prostor Hrvatske i Jugoslavije osim političkih proživljava velike društvene, ekonomske i kulturne promjene. Prvih pet godina novoformirane države ukratko se može opisati kao politički, društveno i ekonomski vrlo teško razdoblje. ${ }^{6}$ Pritom se mora imati na umu da je znatan broj ljudi stradao u ratu i poraću. Tijekom ratnih operacija djelomično ili u cijelosti uništeni su brojni gradovi (Zadar, Pula, Slavonski Brod, Split i dr.) i sela (Vlahović, Podhum, Tršće i dr.). Uz naselja je uništena ionako slaba tehnička infrastruktura (ceste, mostovi, željeznica i dr.).?

Nova država željela se osloboditi prošlosti. Za loše stanje bio je kriv dotadašnji društveni i politički sustav, kojega se trebalo riješiti. ${ }^{8}$ Novi društveno-politički ekonomski sustav temeljio se na socijalističkom uređenju i društvenom vlasništvu. Nacionalizacija, konfiskacija ili eksproprijacija u svim sektorima opravdavala se društveno-ekonomskim ili političkim razlozima. Tim pravnim postupcima stvarala se materijalna baza društvenoga vlasništva, a time i štit od utjecaja stranoga kapitala. ${ }^{9}$ Hoteli, pansioni, lječilišta, kupališta, kao i tvornice te građevinska poduzeća postali su društveno vlasništvo. U tim procesima privatni dio turističke i graditeljske djelatnosti gotovo je zamro. ${ }^{10}$

$S$ obzirom na to da su uočeni brojni problemi u novim društveno-političkim i ekonomskim prilikama, turističku i prostorno planersku djelatnost željelo se provesti na „novim putevima”. Arhitektura je trebala postati „važan faktor zbližavanja ljudi, tvorac ljepšeg života", a arhitekti su okarakterizirani kao "nosioci i realizatori potreba najširih narodnih slojeva”. ${ }^{11}$ Stoga nije neobično što su urbanizam, graditeljstvo i arhitektura u prvim godinama ideologizirani. Za socijalističke gradove i sela te područja ugostiteljsko-turističke namjene traženi su novi prostorno-arhitektonski oblici, koji su trebali služiti za oblikovanje nove stvarnosti, bliske novom čovjeku i njegovim suvremenim potrebama.

6 Uspostavljao se novi društveno-političko-ekonomski sustav, nastupila je ekonomska blokada iz inozemstva, zabilježen je pad poljoprivredne proizvodnje (djelomično uzrokovan kolektivizacijom, a djelomično sušom), bilo je problema s provođenjem prvoga petogodišnjeg plana itd. Vidi: HOLJEVAC TUKOVIĆ, „Društveno-gospodarske reforme 1950-1952. i njihov odraz na upravu Narodne Republike Hrvatske”, 131-146.

7 U Hrvatskoj je za vrijeme rata porušeno 290 naselja i 70.699 kuća. Vidi: KRANJČEVIĆ, Zanemarena baština, 85 .

8 Turistički savez Hrvatske u trideset godina.

9 ANIĆ, „Normativni okvir podržavljenja imovine u Hrvatskoj/Jugoslaviji 1944. - 1946.”, 25-62.

10 Privatni sektor u turizmu sveo se na izdavanje soba u privatnim kućama, a u graditeljstvu na sitne kućne popravke. Takav pristup imao je za posljedicu u prvim godinama nakon rata nisku potrošnju u turizmu, neorganiziranu i nekvalitetnu obnovu zgrada, pojavu stihijske i bespravne izgradnje itd.

11 ŠEGVIĆ, Novi putevi graditeljstva; ŠEGVIĆ, „Za industrijalizaciju graditeljstva”, Slobodna Dalmacija (Split), 11. 7. 1945., 11. 
„Novo društvo"12 tražilo je nove ljude, a svoje razdoblje opisivalo je kao „novo doba” ili „novo vrijeme”. Planovi razvoja bili su obrazlagani i opravdavani time da će novo socijalističko društvo „izgraditi blagostanje”. ${ }^{13}$

Zato je vladala velika potražnja za ionako malobrojnim stručnjacima ${ }^{14}$ koji su bili spremni osmišljavati i provoditi nove, brojne, dinamične, a često i bolne društveno-ekonomske i kulturne procese.

U tim teškim uvjetima nova država svoj razvoj zacrtala je prvim Petogodišnjim planom razvitka narodne privrede FNRJ 1947. - 1951. ${ }^{15}$, koji je bio podloga za snažne modernizacijske procese ${ }^{16}$ kao što su industrijalizacija, elektrifikacija, urbanizacija i dr. Ali kako za plan razvitka nisu sagledani svi čimbenici, brojni ciljevi nisu realizirani.

Samo iz ovih kratkih informacija može se zaključiti da prilike za novi početak nisu bile nimalo lake, pa tako i za osmišljavanje novih modela turističkoga i prostornoga planiranja.

\section{Uvjeti za novi pristup turističkom planiranju od kraja rata do 1950-ih}

Nova država prekinula je kontinuitet međuratnoga razvoja turizma tako da je najprije promijenila cjelokupnu organizaciju uprave i mrežu turističkih udruženja.

Turizam je bio u nadležnosti Odsjeka za turizam i ugostiteljstvo Ministarstva trgovine i opskrbe Narodne Republike (NR) Hrvatske te Saveznoga ministarstva trgovine i opskrbe. U Saveznom ministarstvu 1947. osnovana je

12 ŠEGVIĆ, Novi putevi graditeljstva; ŠEGVIĆ, „Za industrijalizaciju graditeljstva”, Slobodna Dalmacija, 11. 7. 1945., 11.

13 DUDA, U potrazi za blagostanjem; DUDA, „Radim sve što treba'. Aktivisti u mjesnim zajednicama u Jugoslaviji 1970-ih i 1980-ih".

14 Veliki udio nepismenih i slabo obrazovanje zaposlenih u turizmu bilo je prepreka razvoju suvremenoga turizma. U Hrvatskoj je udio nepismenih 1953. iznosio 16,3\%, ali bilo je nepismeno $45 \%$ starijih od 65 godina. U Jugoslaviji je 1953. bilo nepismeno $25,4 \%$ stanovništva. U Hrvatskoj 1961. udio nepismenih iznosi 12,1\%, a 1971. godine 9\%. Iako je Hrvatska u odnosu na druge republike bila urbanizirana, imala je velik udio poljoprivrednoga stanovništva: on je 1948. iznosio 62,4\%, 1953. 56,4\%, 1961. 43,9\%, 1971. 32,3\%. Vidi: Veliki geografski atlas Jugoslavije, 191; KOBAŠIĆ, Turizam u Jugoslaviji, 49-51; ANIĆ, BRKOVIĆ, „Akcijski planovi protiv nepismenosti u Hrvatskoj od 1945. do 1970-ih", 705-729.

15 Od 1947. do 1975. Jugoslavija je imala sljedeće planove društvenoga i ekonomskoga razvoja: Petogodišnji plan razvitka narodne privrede FNRJ 1947. - 1951.; Društveni plan privrednog razvoja Jugoslavije 1957. - 1961.; Društveni plan privrednog razvoja Jugoslavije 1961. - 1965., Društveni plan razvoja Jugoslavije 1966. - 1971., Društveni plan Jugoslavije 1971. 1975. HOLJEVAC TUKOVIĆ, „Društveno-gospodarske reforme 1950-1952. i njihov odraz na upravu Narodne Republike Hrvatske".

16 Jedan od kriterija praćenja društveno-ekonomske razvijenosti bio je stupanj urbanizacije. Hrvatska je 1948. imala samo 25,1\% urbanoga stanovništva. Veliki geografski atlas Jugoslavije, 191. Udio poljoprivrednoga stanovništva iznosio je $62,4 \%$. Procese industrijalizacije i urbanizacije slijedio je proces deagrarizacije i deruralizacije. ŽULJIĆ, Prostorno planiranje $i$ prostorna istraživanja, 145. 
Glavna uprava za turizam i ugostiteljstvo, koja se 1949. organizirala u Komitet za turizam. ${ }^{17}$

Odluka Vlade Jugoslavije o pravu radnika na godišnji odmor (14-30 dana) iz 1946. imala je u prvom redu socijalni karakter i nije bila izravno vezana za planiranje razvoja turizma, ali s tom odlukom poslijeratni domaći turizam Jugoslavije bilježio je rast prometa i smještaja u odmaralištima. ${ }^{18}$

Usprkos atraktivnim prostorima i turističkoj tradiciji (posebno na hrvatskom Jadranu), turizam je pokazivao široku lepezu problema. Tako se ističu posljedice nacionalizacije turističkoga sektora, smjene rukovodećega kadra, loša organizacija i provedba nužne građevinske obnove uništenih zgrada za ugostiteljstvo, slaba opskrba ugostiteljstva hranom i pićem ${ }^{19}$, loša ili nikakva tehnička infrastruktura na svim razinama, slabo ili nikako obrazovan kadar u turizmu ${ }^{20}$, nedostatak financijskih sredstava za izgradnju ugostiteljsko-turističkih zgrada, slab marketing itd. Za inozemne turiste u turističkoj ponudi nedostajali su kvaliteta smještaja, ekskluzivnost, isticanje specifičnosti itd. ${ }^{21}$ Slabosti turizma vidljive su i u slaboj prometnoj povezanosti naselja, slaboj kvaliteti prijevoznih sredstava, slaboj telefonskoj povezanosti i kapacitetu centrala, slaboj informacijskoj mreži, deficitu nekih servisa i zanata, nedostatku zabavno-rekreacijskih sadržaja, održavanju čistoće i higijene itd.

Svi problemi upućivali su na to da turizam zahtijeva ozbiljan i interdisciplinarni pristup. Prvi pokušaj organiziranoga pristupa planiranju turizma razmatrao se na Turističkoj konferenciji održanoj 11. i 12. studenog 1947. u Zagrebu. ${ }^{22}$ Iako je turizam bio predmet Prvoga petogodišnjeg plana razvoja, on nije pokazivao ozbiljnije pozitivne rezultate nakon završetka prvoga planskog razdoblja jer planovi nisu obuhvaćali integralno sagledavanje problema.

Osam godina nakon rata ukupan broj ležajeva na hrvatskom Jadranu iznosio je oko $68 \%$ predratnoga stanja ${ }^{23}$, što pokazuje koliko su rat i poraće utjecali na turizam (tablica 1).

17 Turistički savez Hrvatske u trideset godina.

18 KOBAŠIĆ, Turizam u Jugoslaviji. Uz Odluku o pravu korištenja godišnjeg odmora uvedene su znatne povlastice za članove sindikata i njihove uže obitelji. Povlastice su se odnosile na prijevoz (željeznicom, autobusom, brodom i avionom), smještaj, prehranu u državnim poduzećima i oslobađanje od plaćanja boravišne takse. Te su povlastice 1947. proširene na miliciju i vojsku, a 1948. na članove seljačkih radnih zadruga.

19 Problemi u ugostiteljstvu bili su posebno izraženi nakon blokade istočnoga bloka.

20 KOBAŠIĆ, Turizam u Jugoslaviji. Osim stupnja obrazovanja stalno zaposlenih, veliki problem bili su i sezonski radnici, koji su tijekom sezone činili veći dio zaposlenih u turističkim poduzećima. 1950-ih i 1960-ih osnivane su ugostiteljske škole. Kako sezonski zaposlenici nisu imali stalna primanja, odlazili su u inozemstvo radi stalnoga zapošljavanja.

${ }^{21}$ Isto, 54.

22 FRANIĆ, Razvoj turizma u Makarskoj, 15.

23 BARBIĆ, „Osnovni ekonomski problemi sezonskog ugostiteljstva”, 47-72. 
Tablica 1. Smještajni kapaciteti u primorskim turističkim mjestima NR Hrvatske 1938. i 1953.

\begin{tabular}{|l|c|c|c|c|c|c|}
\hline Godina & Hoteli & Pansioni & Odmarališta & $\begin{array}{c}\text { Ukupno hoteli, pansioni i } \\
\text { odmarališta }\end{array}$ & $\begin{array}{c}\text { Ležajevi u } \\
\text { privatnim } \\
\text { sobama }\end{array}$ & $\begin{array}{c}\text { Ukupno } \\
\text { ležajevi }\end{array}$ \\
\hline 1938. & 201 & 286 & 56 & 543 & 15.647 & 40.344 \\
\hline 1953. & 367 & - & 41 & 408 & 8460 & 27.557 \\
\hline
\end{tabular}

Izvor: BARBIĆ, „Osnovni ekonomski problemi sezonskog ugostiteljstva”, 47-72.

Uvjeti za novi pristup prostornom planiranju turizma od kraja rata do 1950-ih

Nakon Drugoga svjetskog rata graditeljska, urbanističko-arhitektonska i prostorno planerska djelatnost bile su u nadležnosti arhitektonskoga odjela ministarstva građevina na republičkoj i saveznoj razini. Zemaljski gradjevno-projektantski zavod Hrvatske ${ }^{24}$ osnovan je 1946./1947. (ubrzo mijenja ime u Urbanistički institut). Najprije je bio dio administrativno-upravnoga sistema (unutar ministarstva), a poslije je djelovao samostalno. ${ }^{25}$ Zatečeno stanje prostorno-urbanističke dokumentacije nije zadovoljavalo potrebe razvoja republika, gradova i sela. Stoga je 1949. donesena Osnovna uredba o generalnom urbanističkom planu, koja je bila okvir za razvoj suvremene urbanističke prakse u Hrvatskoj i Jugoslaviji. ${ }^{26}$

Osim formiranja tijela uprave, nakon rata obnavlja se rad nekadašnjih stručnih udruženja/društava. U Zagrebu je 1946. osnovan Savez društava inženjera i tehničara FNRJ, a 1950. Društvo arhitekata Hrvatske (DAH). ${ }^{27}$ Društva pokreću stručne časopise, u kojima su prezentirani planovi i projekti. Tako u Zagrebu od 1947. izlazi Arhitektura, a od 1954. Čovjek i prostor. U njima su u prva dva desetljeća autori članaka bili uglavnom domaći autori.

Problema u obnovi gradova i sela u ekonomski nerazvijenoj i ratom stradaloj zemlji bilo je mnogo. Trebalo je djelovati brzo, a nije bilo vremena za izradu detaljnih studija. S obzirom na to da se radilo brzo i mnogo, problemi se nisu mogli šire i kvalitetnije sagledati. Problemi su bili izraženi npr. u nedovoljnoj količini proizvodnje i distribucije građevnoga materijala, često lošoj izvedbi, kao i manjku stručnjaka za planiranje, izvedbu i kontrolu. Stoga

24 Neven ŠEGVIĆ, „Zemaljsko gradjevno-projektantski zavod Hrvatske odigrat će značajnu ulogu u obnovi i izgradnji zemlje i stvaranju naše nove arhitekture”, Vjesnik (Zagreb), 4. 2. 1946., 3. Nešto kasnije osnivaju se urbanistički zavodi u Splitu (1947.), Rijeci, Osijeku i drugim gradovima.

25 Tek reorganizacijom državne uprave 1954. prestaje biti dio administrativnoga aparata.

26 U nedostatku novoga zakona u primjeni je bio Građevinski zakon iz 1931.

27 Prvo savjetovanje urbanista i arhitekata Jugoslavije održano je 1951. u Dubrovniku, zatim 1953. u Zagrebu, 1954. u Ohridu, 1955. u Banji Ilidži, 1956. u Portorožu, 1957. u Aranđelovcu itd. Savez arhitekata Jugoslavije osnovan je 1952. 
su rješenja tražena u tipizaciji i standardizaciji građevnoga materijala, vrsta naselja i pojedinih vrsta zgrada. ${ }^{28}$ Nije bilo neobično što su kvalitetne ideje urbanista i arhitekata realizirane dvadesetak ili tridesetak godina kasnije. ${ }^{29}$

Jedan od prvih poznatih poslijeratnih primjera regulacijskoga odnosno urbanističkoga plana u kojem je istican razvoj turizma jest Generalna regulatorna osnova Makarske iz $1949 .{ }^{30} \mathrm{U}$ prvoj polovini 50-ih godina izrađuju se regulacijski planovi za lječilišna naselja poput onih za Topusko, Šumetlicu (dječje lječilište), Krapinske Toplice itd. ${ }^{31}$ Za naselja koja su imala političku pozadinu, npr. Kumrovec ${ }^{32}$, izrađuje se plan kojim se osim kontinentalnoga želi afirmirati i memorijalni turizam. ${ }^{33}$

Sve se više uviđala potreba za izradom prostornih planova širih područja ${ }^{34}$ koji bi obuhvaćali i usklađivali planove razvoja različitih namjena i sektora.

Za potrebe turizma u prvim godinama nakon rata trebalo je u što kraćem vremenu i sa što manje sredstava osposobiti što veći broj smještajnih kapaciteta jer je naglo rastao domaći turistički promet, posebno u odmaralištima. Izvođeni su najnužniji građevinski popravci i nabavljana je najnužnija oprema, kao i inventar. S obzirom na to da je pristup turističko-graditeljske obnove bio neplanski i nesistematski, ubrzo se pokazalo da je turistička ponuda u svakom smislu bila nekvalitetna. ${ }^{35}$

Problemi turističke ponude nisu bili vidljivi samo u neprimjerenoj kvaliteti smještaja nego i s aspekta urbanizma, graditeljstva i arhitekture. ${ }^{36}$ Uvidom u ne baš vjerodostojne statističke podatke može se zaključiti da je obnova zgrada ugostiteljsko-turističke namjene bila više kvantitativna nego kvalitativna. ${ }^{37}$ Kako je kvantitativna obnova turizma krajem 50 -ih godina upozo-

${ }_{28}$ Tako su među ostalim razmatrani tipovi stambenih zgrada (časopis Građevinar 1955. i 1956.), zadružnih domova uz poštovanje regionalnih oblikovnih karakteristika (vidi: „Nekoliko tipova zadružnih domova iz NRH“, 15-18), hotela za samce itd.

29 Npr. Jadranska magistrala do Makarske realizirana je tek 1965., a Planerski atlas Hrvatske izrađen je 1974.

30 ANTOLIĆ, „Makarska Generalna regulatorna osnova”, 63-64. Iz toga plana vidlijiva je planirana izgradnja ceste - buduće Jadranske magistrale (koja je izgrađena tek 1965.) te nova područja ugostiteljsko-turističke namjene funkcionalističkoga oblikovanja, uklopljena u zelenilo. KRANJČEVIĆ, HAJDINJAK, „Tourism Urbanization in Croatia: The Cases of Poreč in Istria and Makarska in Dalmatia".

31 Vidi monografiju: Urbanistički institut SR Hrvatske 1947-1987.

32 Rodno mjesto predsjednika socijalističke Jugoslavije Josipa Broza Tita.

33 Programska skica za izradu urbanističkog plana Kumrovec iz 1954. sadržavala je prijedlog kampa i druge smještajne zgrade za prihvat turista.

34 UGRENOVIĆ, „Životni zadaci arhitekture i problemi naše tehničke nastave”, 7. Ali u to je vrijeme Urbanistički institut tek bio u osnivanju, a imao je zastarjele karte te mali broj zaposlenih i educiranih za tako ozbiljan zadatak.

35 Kako u pogledu urbanizma, arhitekture i smještaja tako i u pogledu sadržaja.

36 MARASOVIĆ, „O dosadašnjoj turističkoj izgradnji jadranske obale”, 1-9. Nedostaci su bili loša tehničko-tehnološka opremljenost, loša toplinska izolacija, loši sanitarni i higijenski uvjeti, nedostatak parkirališnih mjesta i dr.

37 ALFIER, DOMANIK, „Osnovne pretpostavke o ekonomici i unapređenju našeg turizma", 14-17. 
ravala na brojne probleme, početkom 60-ih počinju se prvi put analizirati prostorno receptivni uvjeti turističke ponude da bi se utvrdili perspektivni potencijali turističke potražnje. ${ }^{38}$ Analiza je pokazala da su mnogi problemi u turizmu rješavani parcijalno u prostornom, sadržajnom i tehničkom smislu. Ubrzo se uvidjelo da za kvalitetan turizam nije dovoljno uređenje pojedine zgrade ugostiteljsko-turističke namjene, nego je trebalo osigurati tehničku infrastrukturu (vodoopskrbu, električnu energiju, odvodnju, prometnice i dr.), i to ne samo određenoga naselja ili njegovih dijelova nego i regija i republika. Bilo je potrebno dignuti razinu prostornoga planiranja turizma. Dotadašnje planiranje pokazivalo je znakove neorganiziranosti i nekoordiniranosti is turizmom i s drugim sektorima. Zato nije neobično da je kvaliteta hotela bila uvelike ispod europske razine. Stoga je turizam trebalo više povezati s prostorom i oblikovanjem, odnosno prostornim planiranjem kojim se mogu stvarati prostorne pretpostavke za turističku arhitekturu.

\section{Prema turističkom planiranju 1960-ih}

Brza i nekvalitetna poslijeratna obnova zgrada ugostiteljsko-turističke namjene ukazivala je na složene i brojne probleme. Za kvalitetniji turizam trebalo je uskladiti različite sektore u različitim prostorima (regijama) jer turizam nije prodirao samo na pojedine dijelove jugoslavenske obale nego svuda, ne čekajući osiguranje tehničkih, organizacijskih, administrativnih ili pravnih uvjeta. Stoga se novim generacijama društvenih planova razvoja ${ }^{39}$ željelo više uskladiti pravce razvoja različitih sektora i njihove provedbene mjere da bi turizam pokazao kvalitetne rezultate. Radi pokušaja kvalitetnijega razvoja turizma osnivana su veća i manja državna turistička poduzeća, koja su bila glavni nositelji intenzivne hotelske izgradnje.

Turizam je od 1952. bio u nadležnosti Sekretarijata za robni promet. U to vrijeme osniva se ugostiteljska komora i obnavlja rad nekadašnjih turističkih društava. Nakon osnivanja regionalnih turističkih društava, 1953. osnivaju se Turistički savez Hrvatske i Turistički savez Jugoslavije. ${ }^{40}$ Iste godine započelo je u Zagrebu izdavanje časopisa Turizam, u kojem su priloge objavljivali samo domaći autori ${ }^{41}$, koji su stručno, kritički i afirmativno pisali o turizmu te predlagali određena rješenja. ${ }^{42}$

38 MARASOVIĆ, „O dosadašnjoj turističkoj izgradnji jadranske obale”.

39 Nakon Petogodišnjega plana razvitka narodne privrede FNRJ 1947. - 1951. uslijedila je pauza od nekoliko godina. Sljedeći plan bio je Društveni plan privrednog razvoja Jugoslavije 1957. - 1961.

40 Turistički savez Hrvatske u trideset godina, 40. Slovenija je osnovala Turistički savez Slovenije 1950.

${ }^{41}$ Iznimku 1962. čini Kurt Krapf iz Švicarske jer se početkom 1960-ih Jugoslavija počela otvarati inozemnom turizmu.

42 Taj časopis danas je važan izvor podataka o promišljanju i planovima razvoja turizma u Hrvatskoj i Jugoslaviji u vrijeme socijalizma. 
Društvo ekonomista Hrvatske također je željelo unaprijediti stanje turizma, pa je 1954. u Dubrovniku organiziralo savjetovanje o problemima turističke privrede. ${ }^{43}$ Sljedeće godine u sklopu Društva osnovana je Sekcija za turizam, koja je s Ekonomskim fakultetom i Turističkim savezom Hrvatske organizirala skupove na kojima se raspravljalo o praktičnim i teorijskim problemima turizma. Predlagalo se osnivanje posebne ustanove za proučavanje turizma u Dubrovniku, ali Komora za hotelijerstvo i ugostiteljstvo Hrvatske u Zagrebu osnovala je 1959. Biro za turističko-ugostiteljsku izgradnju - danas Institut za turizam. ${ }^{44}$

S obzirom na to da je turizam povezan s različitim sektorima, formiran je posebni Savjet za turizam, čiji su članovi bili predstavnici različitih sektora, a bavio se formiranjem opće turističke politike.

Novom reorganizacijom državne uprave na saveznoj razini sredinom 1963. osnovan je Savezni komitet za turizam, a krajem iste godine u Hrvatskoj Republički komitet za turizam. Od 1965. turizam je u nadležnosti jedinstvenoga Sekretarijata za privredu Socijalističke Republike (SR) Hrvatske. Izvršno vijeće Sabora, kao zakonodavno tijelo, 1969. osnovalo je Komitet za turizam. ${ }^{45}$

Što se tiče cijena u turizmu, sve do 1951. one su bile dvojne - za domaće i za strane turiste. ${ }^{46}$ Od 1952. uvode se specifične mjere stimulacije za korištenje odmora domaćih turista u komercijalnom ugostiteljstvu. Od 1957. do 1965. porastu domaćega turizma pridonio je razvoj životnoga standarda građana, rast osobne potrošnje, ali i razne mjere za stimulaciju razvoja smještajnih kapaciteta. Time je započeo rast broj ležajeva u ugostiteljstvu i u Hrvatskoj i u drugim republikama (tablice 2 i 3 ).

43 Zbornik radova izdan je 1955. pod naslovom Zbornik rasprava o problemima turističke privrede.

${ }^{44}$ Predloženo je da se Arhiv za turizam u Dubrovniku pretvori u znanstvenu ustanovu institutskoga tipa, ali ta inicijativa nije ostvarena. Vidi: Turistički savez Hrvatske u trideset godina. Ubrzo su zadaci i aktivnosti Biroa prerasli prvobitnu ideju osnivanja - izradu investicijskih studija i analiza, što je u početnoj fazi turističkoga razvoja, kasnih 50-ih godina, bio glavni razlog za njegovo osnivanje. Sa širim razumijevanjem turizma proširivali su se poslovi i zadaci u turizmu te je Biro 1965. promijenio ime u Institut za ekonomiku turizma.

45 Turistički savez Hrvatske u trideset godina, 43.

${ }^{46}$ KOBAŠIĆ, Turizam u Jugoslaviji, 11. Domaći turisti imali su popuste 10-25\% u odnosu na strance, a to je ovisilo o turističkoj sezoni. 
Tablica 2. Broj ležajeva, ukupan broj noćenja u tisućama, dolazaka u tisućama, društveni proizvod ${ }^{47}$ u milijunima dinara cijena 1972.

\begin{tabular}{|c|c|c|c|c|c|c|c|c|}
\hline $\begin{array}{c}\text { Godi- } \\
\text { na }\end{array}$ & \multicolumn{2}{|c|}{$\begin{array}{c}\text { Broj ležajeva u } \\
\text { ugostiteljstvu }\end{array}$} & \multicolumn{2}{c|}{$\begin{array}{c}\text { Ukupan broj } \\
\text { noćenja u } \\
\text { tisućama }\end{array}$} & \multicolumn{2}{c|}{$\begin{array}{c}\text { Ukupan broj } \\
\text { dolazaka u } \\
\text { tisućama }\end{array}$} & \multicolumn{2}{|c|}{$\begin{array}{c}\text { Društveni } \\
\text { proizvod }\end{array}$} \\
\hline & SFRJ & Hrvatska & SFRJ & Hrvatska & SFRJ & Hrvatska & SFRJ & Hrvatska \\
\hline 1955. & 90.182 & 39.444 & 11.087 & 5106 & 3411 & 1089 & - & - \\
\hline 1956. & - & - & - & - & - & - & 76.996 & 21.768 \\
\hline 1960. & 254.095 & 151.561 & 23.023 & 11.164 & 5188 & 1773 & 118.283 & 31.708 \\
\hline 1965. & 444.459 & 286.908 & 32.651 & 18.130 & 7942 & 3017 & 164.658 & 43.686 \\
\hline 1970. & 697.301 & 453.071 & 48.503 & 28.551 & 11.860 & 4804 & 217.947 & 58.344 \\
\hline 1975. & 937.053 & 614.640 & 70.427 & 42.411 & 15.545 & 6454 & 289.893 & 75.410 \\
\hline
\end{tabular}

Izvor: Veliki geografski atlas Jugoslavije, 220, 201; Turistički savez Hrvatske u trideset godina, 168-169.

Turistički promet u svijetu rastao je brže nego svjetski izvoz. Kako je država bila zainteresirana za pribavljanje deviza preko turizma, nije bilo neobično da se u planovima razvoja sve više isticao potencijal turizma i njegova izvozna komponenta. Jugoslavija i Hrvatska sve su se više otvarale inozemnom turizmu, projektima i kreditima. S obzirom na to da su međunarodnim kreditima financirani širi programi razvoja zemlje, turizam je trebalo inkorporirati u planove općega razvoja.

Tablica 3. Broj ležajeva po republikama 1960. - 1970.

\begin{tabular}{|lr|c|r|c|}
\cline { 2 - 5 } \multicolumn{1}{c|}{} & \multicolumn{2}{c|}{$\mathbf{1 9 6 0 .}$} & \multicolumn{2}{c|}{1970.} \\
\cline { 2 - 5 } \multicolumn{1}{c|}{} & Broj ležajeva & \% & Broj ležajeva & \% \\
\hline Hrvatska & 151.561 & 59,6 & 453.071 & 65 \\
\hline Srbija & 37.639 & 14,9 & 74.096 & 10,6 \\
\hline Crna Gora & 13.305 & 5,3 & 63.122 & 9,1 \\
\hline Slovenija & 32.782 & 12,8 & 69.819 & 10 \\
\hline Makedonija & 10.626 & 4,2 & 20.127 & 2,9 \\
\hline Bosna i Hercegovina & 8182 & 3,2 & 17.066 & 2,4 \\
\hline SFRJ & 254.095 & 100 & 697.301 & 100 \\
\hline
\end{tabular}

Izvor: STANKOVIĆ, Turizam u Jugoslaviji, 144.

Privredna reforma 1965. dovela je ugostiteljstvo i turizam u bolji položaj. ${ }^{48}$ Tako je 1965. domaći turizam više prepušten tržištu i djelomičnoj brizi radnih

47 Veliki geografski atlas Jugoslavije, 240. Značenje pojma: „društveni proizvod, kao vrijednosni izraz rezultata finalne proizvodnje, iskazuje se u vidu zbroja narodnog dohotka i amortizacije." Nakon Srbije, Hrvatska je imala drugi najviši društveni proizvod u Jugoslaviji.

48 Turistički savez Hrvatske u trideset godina, 105. 
kolektiva za odmor svojih članova. Dok se turistički promet inozemnih turista prvih godina nakon rata uglavnom svodio na turiste iz istočnoga bloka, otvaranjem zemlje prema Zapadu sve je više turista bilo iz Njemačke, Austrije, Italije i drugih država. Tako je udio noćenja koji su ostvarili inozemni turisti u Jugoslaviji sve više rastao. Godine 1952. iznosio je 5,8\%, 1960. godine $15,3 \%$, 1965. godine $34,4 \%$, a 1970 . godine $46,5 \% .{ }^{49}$

Zbog priljeva deviza od inozemnoga turizma, u Društvenom planu razvoja Jugoslavije 1966. - 1970. turizam je uvršten među prioritetne pravce razvoja gospodarstva. Uslijedile su brojne poticajne mjere za razvoj turističke ponude u tom planskom razdoblju. Tim planom turističkim poduzećima omogućeno je ugovaranje inozemnih kredita i drugih aranžmana za izgradnju zgrada ugostiteljsko-turističke namjene itd. Država je željela od inozemnoga turizma ostvariti maksimalnu korist za sebe te je planere potaknula na izradu projekcija koje su optimistički predočavale mogućnosti turizma. Te projekcije trebale su potaknuti nositelje politika da u planovima razvoja posvete turizmu odgovarajuću pozornost. Zbog toga se potkraj 60-ih pojavljivao raskorak između planova i ostvarenja u turizmu. ${ }^{50}$ Turizam je poprimao neočekivane razmjere, koji su se očitovali u spontanom, ali naglom porastu turističkih smještajnih kapaciteta (više od planiranoga), snažnom porastu domaćega i inozemnoga turističkog prometa te porastu investicijskih zahvata u turizmu.

\section{Turizam i politička tijela}

S obzirom na njegovu važnost za državu, turizam je postao predmet razmatranja političkih organizacija poput Socijalističkoga saveza radnog naroda Jugoslavije i Saveza komunista na svim razinama. Tako se ističe rasprava o turizmu 1960. na V. kongresu Socijalističkoga saveza radnog naroda Jugoslavije. Tom prilikom predsjednik Jugoslavije Josip Broz Tito istaknuo je važnost turizma i ugostiteljstva za ekonomiju „ne samo zato što omogućava veliki priliv deviznih sredstava, nego i zato što znače neophodnu potrebu za pružanje turističko-ugostiteljskih usluga našim građanima, koje također zauzimaju važno mjesto u podizanju životnog standarda”. Politički vrh isticao je pozitivne učinke turizma na ekonomiju, društvo i opći razvoj, a prezentirani su kao rezultat odgovornoga i planskoga razvoja države te kao „dosadašnji uspjesi i pobjede u izgradnji socijalističkog društva”. Isticalo se i da je socijalizmom „ukazano na sve faktore, koji su stvorili uslove za takav golem napredak, kakav je postigla rijetko koja zemlja u svijetu". ${ }^{51}$

49 KOBAŠIĆ, Turizam u Jugoslaviji, 19.

50 Isto, 27.

51 Iz govora Josipa Broza Tita na V. kongresu Socijalističkoga saveza radnog naroda Jugoslavije. Vidi: „Perspektive privrednog razvoja i turizam”. 
„Ulaganja u ugostiteljstvo omogućit će da se izgradnjom novih i rekonstrukcijom postojećih objekata u turističkim mjestima, broj ležaja poveća do kraja 1965. godine za preko 50\% u odnosu na 1958. Usporedo s tim predviđa se i brzi razvoj kapaciteta društvene ishrane, naročito u većim naseljima i turističkim centrima." ${ }^{2}$

Turizam je bio predmet i IV. plenuma Centralnoga komiteta Saveza komunista Jugoslavije 1962., na kojem je predsjednik Tito uspoređivao turizam Italije i Jugoslavije. Naveo je da je Italija 1962. očekivala od turizma milijardu dolara, a Jugoslavija je 1961. ostvarila samo 24 milijuna dolara, te je time upozorio na velike potencijale priljeva deviza od turizma. ${ }^{53}$

Turizam je bio predmet i IX. kongresa Saveza komunista Jugoslavije 1969., a predsjednik Jugoslavije zaključio je da turizmu treba posvetiti ,još veću pažnju”. ${ }^{54}$

\section{Turizam i promocija}

Razvoj turizma među ostalim ovisi i o promociji. Prema uzoru na predratne, izdavani su novi turistički vodiči za cijelu Jugoslaviju, a ne samo za pojedina turistička odredišta, na vlastitim i stranim jezicima. U Zagrebu je 1958. objavljen Ilustrirani turističko privredni i hotelski vodič FNR Jugoslavije, koji je doživio više izdanja.

Davanjem sve većega značenja turizmu, turistička poduzeća i turističke zajednice prezentirali su se na Zagrebačkom velesajmu, koji su posjećivali brojni građani, ali i politički dužnosnici. Na Jesenskom velesajmu 1961. organizirana je Komercijalna izložba turizma, na kojoj su sudjelovala 54 izlagača iz cijele Jugoslavije, a bila je opsežnija i raznovrsnija od dotadašnjih. ${ }^{55} \mathrm{Da}$ je turistički sektor sve više dobivao na značenju vidljivo je po tome što su sljedeći Jesenski velesajam 1962., na kojem je prezentiran turizam, posjetili državni vrh i predsjednik Jugoslavije. On je tom prilikom izjavio da je potrebno „mijenjati politiku u turizmu”, a na njegovu složenost upozorio je izjavom: „Pitanje turizma treba ozbiljno proučiti i poduzeti sve potrebne mjere." ${ }^{\prime 6}$ Rekao je i da k nama turisti dolaze zbog ljepota naših otoka i obale te istaknuo potrebu podizanja kvalitete pružanja usluga i nedostatak ugostiteljskih kadrova. Turi-

52 Isto, $1-2$.

53 „Predsjednik Tito o turizmu”, 1; „Treba mijenjati politiku u turizmu”, 1.

54 „Razvoju turizma moramo posvetiti još veću pažnju - iz referata Josipa Broza Tita na devetom kongresu Saveza komunista Jugoslavije", 1.

55 Izložbu je posjetio predsjednik Izvršnoga vijeća NR Hrvatske Jakov Blažević, koji je naglasio „da prilaženje rješavanju pojedinih i kompleksnih problema turističke privrede treba da bude studiozno. To mogu da učine visokokvalificirani kadrovi koji treba da odlučno zahvate sve komponente koje u nekoj komuni, kao i zaokruženoj ekonomskoj ili geografskoj cjelini dolaze u obzir kod razrade problema turističkog razvitka”. Vidi: „Turizam na jesenjem ZV”, 14-16.

56 „Treba mijenjati politiku u turizmu”, 1. 
zam je povezao s domaćom poljoprivrednom proizvodnjom i proizvodnjom hrane, koje je potrebno koristiti u turizmu. ${ }^{57}$

Da bi se pokazala povezanost države i turizma, odnosno da socijalističko društvo izgrađuje novi turizam, 1966. u Ilustriranom privrednom turističkom $i$ hotelskom vodiču po Jugoslaviji nakon korica objavljen je slogan Jugoslavija zemlja socijalizma, prirodnih ljepota $i$ turizma. ${ }^{58}$

\section{Prema prostornom planiranju turizma 1960-ih}

Hrvatska i Jugoslavija imale su brojne preduvjete za razvoj turizma atraktivan prostor, povoljan geografski položaj i klimu, bogato kulturno i prirodno nasljeđe itd., a ideje je trebalo inkorporirati u prostorne planove i opći razvoj. To je vidljivo iz časopisa Turizam, u kojem se početkom 60-ih godina objavljuje serija članaka o važnosti prostornoga i regionalnoga planiranja, a autori su uglavnom ekonomisti i arhitekti. Tako 1962. Dragutin Alfier piše o važnosti turizma u prostornim planovima, a Neda Andrić sa suradnicima o regionalnom aspektu planiranja turizma. Godine 1963. o važnosti izrade prostornih planova za turistička područja piše arhitekt Bruno Milić, a o prostornom planiranju u zaštićenim područjima na jadranskoj obali arhitekt Boris Ševčik; arhitekt Dragan Boltar te arhitekt i slikar Josip Seissel pišu o trenutačnom razvoju jugoslavenske obale Jadrana, a ekonomisti Franjo Gašparović i Ante Mihletić o povezanosti turizma i poljoprivrede.

Osim što je služio za podizanje društvenoga blagostanja, turizam je bio instrument za urbanizaciju i osuvremenjivanje brojnih naselja. ${ }^{59}$ Izgradnjom hotela ili hotelskih sklopova mala ribarska naselja doživjela su snažnu transformaciju prostora. Izgradnjom hotela, koji su volumenom dominirali u prostoru, dobila su novi prostorni identitet, ali i osuvremenjenu ili novu tehničku infrastrukturu (ceste, luke, vodovod, kanalizacija, električna mreža, telefonska mreža i centrala itd.) te društvenu infrastrukturu (banka, trgovina, zdravstvena ustanova i dr.).

Da bi prostorni planovi imali približno isti sadržaj, sve se više raspravljalo o metodologiji njihove izrade.

Društveni plan privrednog razvoja Jugoslavije 1957. - 1961. poticao je razvoj turizma, ali ni on još nije obuhvaćao kompleksno i slojevito pitanje turističke izgradnje jer nije bilo podataka o prostornoj distribuciji turizma, turističkim smještajnim kapacitetima u odnosu na strukturu i lokaciju, kategorizaciji i drugome na regionalnim razinama. Za izradu planova razvoja turizma na republičkim i nižim razinama trebalo je sakupiti podatke o postojećem stanju obale i njezinim mogućnostima s različitih aspekta, kojih tada također nije bilo. Stoga je trebalo sakupiti i analizirati prirodno-geografske,

57 Isto.

58 MATOŠIĆ, Ilustrirani privredni turistički i hotelski vodič po Jugoslaviji, 3-4.

59 ENSMINGER, „Urbanizacija sela putem razvoja turizma”, 10-12. 
demografske, ekonomske, kulturne, prirodne i prometne uvjete da bi se sagledalo postojeće stanje i na temelju njega izraditi smjernice za novu prostornu distribuciju turizma.

\section{Prostorni planovi turizma}

Krajem 50-ih godina zahvaljujući povoljnim društvenim i ekonomskim prilikama turizam je sve više izazvao zanimanje vlasti, a time i javnosti. U Hrvatskoj je Izvršno vijeće Sabora NR Hrvatske početkom 1959. raspravljalo o povećanju smještajnih, prehrambenih i drugih turističkih kapaciteta te uputilo narodnim odborima preporuku da odmah pristupe razradi programa za unaprjeđenje turizma i ugostiteljstva u skladu s potrebama razvoja turizma. ${ }^{60}$

Kako nije bilo iskustava u izradi dugoročnih republičkih ni regionalnih prostornih planova kojima bi se u prostoru uskladile različite namjene, nakon inicijative za izradu regionalnoga plana kotara Krapina 1954. pristupilo se izradi metodologije regionalnoga planiranja, koja je u Hrvatskoj prihvaćena 1956. godine. Na temelju te metodologije izrađen je u Hrvatskoj regionalni plan kotara Krapina ${ }^{61}$, koji je služio kao osnova za testiranje metodologije za izradu regionalnih planova.

Zbog specifičnih uvjeta u turizmu prostorni planovi turizma također su zahtijevali osmišljavanje specifične metodologije. Komisija za turizam Izvršnoga vijeća Sabora NR Hrvatske potaknula je 1959. izradu Metodologije $i$ uputstava za izradu dugoročnog programa razvitka turizma jer Društveni plan privrednog razvoja Jugoslavije 1957. - 1961. nije obuhvaćao pitanja prostornih potencijala i turističke izgradnje. Stručnjaci Urbanističkoga instituta Hrvatske prvi su u Jugoslaviji razvili metodologiju dugoročnoga programa razvitka turizma. Metodologija je obuhvaćala analizu postojećih prostornih i tehničkih turističkih uvjeta, a služila je kao pomoć za tzv. rajonizaciju turističkih područja da bi se definirala vrsta i karakter turizma te potrebna turistička izgradnja uz primjenu prostornoga kriterija.

U skladu s Društvenim planom privrednog razvoja 1957. - 1961. na republičkoj razini, za razinu kotara izrađen je Perspektivni plan razvoja turizma $i$ ugostiteljstva kotara Makarska za 1957. - 1961. Na temelju Perspektivnoga plana uslijedila je izrada Regionalnoga prostornog plana za Makarsko primorje 1958. - 1961. To je prvi regionalni prostorni plan turizma na hrvatskoj obali Jadrana (oko $47 \mathrm{~km}$ obale) u čijoj su izradi primijenjeni prihvaćeni metodološki temelji prostornoga planiranja turizma. Planom su određeni osnovni okviri i smjernice prostornoga aspekta turizma. Stoga su osim prostornoga razmještaja pojedinih turističkih građevina detaljno određivane vrste i broj

60 Turistički savez Hrvatske u trideset godina, 82-83.

${ }^{61}$ Regionalni prostorni plan kotara Krapine donesen je 1958., malo je obrađivao turizam, a izradio ga je tadašnji Urbanistički institut NR Hrvatske. Glavni planeri bili su arhitekt Branko Petrović i geograf Stanko Žuljić. 
smještajnih kapaciteta. Područja ugostiteljsko-turističke namjene detaljno su analizirana u odnosu na osnovne infrastrukturno-tehničke uvjete, pošumljenost, karakteristike plaže, uvjeta za razonodu, poljoprivredne površine i proizvodnju, stanje trgovačke mreže i ugostiteljskih objekata turističkoga prometa, poštanski promet itd. U planu se upozoravalo na potrebu izvođenja složenih predradnji za pokretanje intenzivne izgradnje zgrada ugostiteljsko-turističke namjene i dalekosežne posljedice na prostor. ${ }^{62}$

$\mathrm{Na}$ osnovi prostornoga plana turizma za Makarsko primorje uslijedila je izrada Plana za obalno područje kotara Šibenik 1960.

Tijekom 60-ih u urbanističkim institutima i na fakultetima stvarala se široka baza prostornih podataka da bi se sagledao i usmjerio razvoj hrvatskoga, ali i jugoslavenskoga Jadrana (koji danas obuhvaća četiri države). Taj prostor želio se sagledati i planirati kao jedinstveni prostor. Ali sve pretpostavke još nisu bile osigurane, npr. suglasnost svih republika. ${ }^{63}$

S obzirom na to da je turizam postao strateški savezni i republički cilj općega razvoja, sagledavao se kroz razvoj na lokalnoj, regionalnoj, republičkoj i saveznoj razini. Za potrebe „rajonizacije”64 izrađena je 1965. studija Tržišni aspekti $i$ raspored turističke potražnje kao podloga za turističku rajonizaciju jadranskoga područja. U studiji je rađena procjena planirane veličine i prostornoga rasporeda turističkoga smještaja (po mikroregijama) i izgradnje na temelju ukupne dužine obale pogodne za kupanje. Zanimljivo je da su brojniji smještajni kapaciteti planirani za Dalmaciju nego za Istru i Kvarner. Ali zbog boljih postojećih tehničko-infrastrukturnih i institucionalnih uvjeta, kao i tradicije turizma, u Istri i na Kvarneru izgrađen je veći broj smještajnih kapaciteta u hotelima.

Uz suradnju drugih institucija Urbanistički institut Hrvatske bio je glavni nositelj izrade Programa dugoročnog razvoja i plana prostornog uređenja jadranskog područja knj. 15-4365 (popularno zvan Veliki Jadran), koji je poslije služio kao podloga za brojne nove planove. ${ }^{66}$

${ }^{62}$ Regionalni plan turističke izgradnje obalnog područja od Brela do Podgore, odnosno Makarskoga primorja, bio je prvi pokušaj izrade prostornoga plana za potrebe turizma na regionalnoj razini u Hrvatskoj. Plan je izradio Zavod za urbanizam Arhitektonskog, građevinskog i geodetskog fakulteta iz Zagreba u suradnji s Biroom za turističko-ugostiteljsku izgradnju (danas Institut za turizam) iz Zagreba. Glavni autori plana su prof. ing. Josip Seissel, prof. ing. Dragan Boltar i Silvana Seissel. Vidi: FRANIĆ, Razvoj turizma u Makarskoj, 30; KRANJČEVIĆ, „Turizam u prostornim planovima Makarskog primorja od 1945. - 1990.”, 211-230.

${ }_{63} \mathrm{U}$ to vrijeme karte nisu bile digitalizirane, a osiguranje karata cjelovitoga područja bilo je pod kontrolom vojske.

${ }^{64}$ Hrvatski Jadran bio je podijeljen na sljedeće turističke regije: Zapadna Istra, Kvarner i Hrvatsko primorje (Kvarner, Rijeka, Vinodol, Senj, Karlobag), Sjeverna Dalmacija, Srednja Dalmacija (Šibenik, Split, Makarska, Hvar i Vis), Južna Dalmacija (Korčula i Dubrovnik).

${ }^{65}$ Program dugoročnog razvoja i plan prostornog uređenja jadranskog područja, knj. 15-43.

${ }_{66}$ Za 18 elaborata izrađene su studije, od kojih se ističu Uslovi održanja $i$ unapređenja našeg dijela Jadrana, priobalnog područja i plaža sposobnih za razvoj turizma (autor prof. ing. Dragan Boltar) te O dosadašnjoj turističkoj izgradnji jadranske obale (autori Miro Marasović, dipl. ing. arh., i Viktor Hećimović, dipl. ing. arh.). 
Uslijedila je izrada Regionalnoga prostornog plana Južnog Jadrana, koji je obuhvaćao obalu Crne Gore, Bosne i Hercegovine te dijela Hrvatske - Dalmacije (dovršen 1968.). Rađen je s ciljem pronalaženja optimalne društveno-ekonomske, a osobito prostorne funkcije turizma u općem razvoju južnojadranske regije i turističkom razvoju zemlje kao cjeline.$^{67}$ Taj plan bio je financiran sredstvima Razvojnoga programa Ujedinjenih naroda (United Nations Disengagement Program - UNDP) i Vlade Socijalističke Federativne Republike Jugoslavije (SFRJ). ${ }^{68}$

Osim za područje Jadrana, turizam se planirao i za kontinentalni dio Hrvatske. Na turističke razvojne potencijale grada Zagreba, njegove okolice i Hrvatskoga zagorja upozoreno je u Prostornom planu razvoja turizma i rekreacije u gravitacionom području Zagorske magistrale 1963. godine. Zanimljivo je da su te godine smještajni kapaciteti planirani u lječilištima (toplicama), novoizgrađenim i planiranim hotelima, planiranim kampovima, postojećim dvorcima i kućnoj radinosti. ${ }^{69}$

Regionalni prostorni plan Istre izrađen 1969. sadržavao je prostornu distribuciju turizma u odnosu na opći razvoj, postojeći i očekivani broj stanovnika i dr.

Bez obzira na kvalitetu prostornih planova turizma na razini regije, pri provedbi na nižim razinama (kotar, općina) evidentirana su odstupanja, a ostvarena se izgradnja $s$ vremenom u određenoj mjeri deformirala. ${ }^{70}$ Zato nije neobično što se krajem 60 -ih i početkom 70 -ih godina prošloga stoljeća javljaju prvi osvrti na ostvarene rezultate utjecaja turizma na prostor. Eugen Franković 1967. i Milan Prelog 1973. upozoravali su na (pozitivne i negativne) posljedice turističke izgradnje na prostor, ali i na snažnije uključivanje korištenja kulturnih dobara i krajolika u turizmu. Arhitekt Ante Marinović-Uzelac 1986. ukazivao je na nerealnost prostornih planova turizma, posebno zbog ograničenosti prostora (nije beskonačan) i budućega održavanja zgrada. ${ }^{71}$

${ }^{67}$ Regionalni prostorni plan Južnog Jadrana izrađivali su Urbanistički institut SR Hrvatske, Republički zavod za urbanizam SR Crne Gore i Urbanistički zavod SR Bosne i Hercegovine uz suradnju Instituta za ekonomiku turizma iz Zagreba te međunarodnoga konzultativnoga konzorcija TEKNE (Milano - Varšava) i SWECO (Švedska).

68 Na kraju 60-ih započela je izrada Koordinacionoga regionalnog prostornog plana, koji je izrađen 1972.

69 Navedeni plan izradio je Urbanistički institut Hrvatske u suradnji sa stručnjacima Biroa za turističku izgradnju. Odgovorni planeri bili su Zdenko Chavrak i Fedor Wenzler, a suradnici Srđan Marković i Dragutin Kiš. KRANJČEVIĆ, „Promet i turizam u prostornim planovima na području Hrvatskog zagorja 1958. i 1963.", 3-7.

70 KOBAŠIĆ, Turizam u Jugoslaviji, 62; GAŠPAROVIĆ, „Problemi prostornog planiranja turističkih područja”, 382-403; GAŠPAROVIĆ, ŠALAT, „Osnovna razmatranja u planiranju razvoja turističkih područja. Primjer - Projekt Južni Jadran”, 728-747.

${ }^{71}$ MARINOVIĆ-UZELAC, Naselja, gradovi, prostori. Održavanje i osuvremenjivanje hotelske arhitekture svakako treba razmatrati u sklopu gospodarenja vlasništvom. Održavanje se može povezati sa zakonskom regulativom o povezivanju prava i odgovornosti vlasnika. Stoga nije neobično što je znatan broj hotelske arhitekture napušten, posebno nakon 1991. (rezultat pretvorbe ili posljedica ratnih razaranja), usprkos svim turističkim potencijalima odredi- 
Analizirajući prostorne planove turizma, može se primijetiti da su s godinama bili sve više usklađeni i koordinirani ne samo na razini regija, republika i države nego i različitih sektora, investicija i naselja. Usprkos sve većoj usklađenosti, pokazivali su znakove nerealnih planova jer nisu uzimani u obzir svi čimbenici, npr. oni za daljnju realizaciju (dekonstrukcija političkoga sustava, mogućnosti institucionalne provedbe itd.).

\section{Intenzivna društvena hotelska izgradnja}

Suvremeni kvalitetan smještaj mogli su pružiti jedino novi hoteli. S obzirom na to da je turistička društvena izgradnja trebala biti odraz modernoga socijalističkog društva, bilo je potrebno podignuti kvalitetu hotela. A da bi područja ugostiteljsko-turističke namjene kao i hotelska arhitektura mogli pružiti kvalitetan smještaj te biti konkurentni inozemnom, 60-ih godina zauzet je stav da je u turizmu potrebno praćenje međunarodnih trendova, pa i u opremanju hotela. ${ }^{72} \mathrm{Za}$ to su preko općih javnih ili pozivnih urbanističko-arhitektonskih natječaja angažirani domaći arhitekti.

Kako je država omogućila kreditiranje domaćih društvenih turističkih poduzeća, uslijedila je intenzivna hotelska izgradnja, uglavnom na obali. Tako je turistička arhitektura 50-ih i 60-ih na hrvatskoj obali Jadrana transformirala prostor izgradnjom hotela kao što su Jadran u Tučepima (1949.), Zagori u Novom Vinodolskom (1960.), Dječje lječilište Krvavica (1961.), Ambasador u Opatiji (1962.), Pelegrin u Kuparima (1963.), Santa Andrea u Rapcu (1963.), Resnik u Resniku (1965.), Jadran u Omišlju (1966.), Girandela u Rapcu (1969.) itd. Uređuje se i gradi na Brijunima, koji su postali državna rezidencija (nacionalni park od 1983.), te vojno odmaralište Kupari u Kuparima. ${ }^{73}$

Razvoj turizma i investicije u izgradnju potaknuli su razvoj hotelske arhitektonske misli te su u arhitektonsko-konstruktivnom smislu izvedeni novi oblici zgrada ugostiteljsko-turističke namjene: paviljonski tipovi hotela, terasasti hoteli, atrijski tip hotela, hotelska naselja i dr. U oblikovanju novih zgrada ugostiteljsko-turističke namjene 50-ih i 60-ih godina primjenjivana su isključivo stilska načela moderne. ${ }^{74}$ Turistička arhitektura sve se više povezi-

šta. Vidi: KRANJČEVIĆ, STOBER, „Potreba inventarizacije napuštenih izgrađenih područja - nužnost za planiranje turizma u kontinentalnoj Hrvatskoj”; KRANJČEVIĆ, „Abandoned Tourism Resorts in Croatia: The consequences of discordant spatial planning and tourism development policies".

72 Sve veći turistički promet ukazivao je na problem loših smještajnih kapaciteta, kvalitete gradnje, kvalitete opremanja i javne tehničke infrastrukture. Vidi: MARASOVIĆ, „O dosadašnjoj turističkoj izgradnji jadranske obale”.

73 U projektiranju hotelske arhitekture 60-ih ističu se Branko Bonn, Branko Vasiljević, Branko Petrović, Rikard Marasović, David Finci, Zdravko Bregovac, R. Bukovac, Branimir Gruica, Ante Čičin-Šain, Lavoslav Horvat, Ljudevit Gaj i dr.

74 Pri rekonstrukciji hotela izgrađenih krajem XIX. i početkom XX. stoljeća, koji su imali historicističko oblikovanje i/ili namještaj, često je „brijano” pročelje tako da su uklanjani ornamenti, kao i ostaci namještaja. 
vala sa širim područjima te se pri izradi prostornih planova turizma i projektiranju turističke arhitekture velika pozornost posvećivala odnosu izgrađenih i neizgrađenih površina, sadnim površinama, planiranju sportsko-rekreativnih, zabavnih i kulturnih sadržaja itd.

Iako je privatni sektor $\mathrm{u}$ turizmu kroz privatni smještaj bio zanemaren $\mathrm{u}$ planovima razvoja turizma (uglavnom planiran kao dopunski smještaj), on je također bujao. ${ }^{75}$

Novi pristup oblikovanju turističke arhitekture često je opravdavan dvostrukim obrazloženjem. Jedno je da se svijetu pokaže pozitivna strana socijalizma, a drugo da se prikažu ideje za odmor radnika, koje su se često pokazivale kao utopija. ${ }^{76}$ Planirani su hoteli, odmarališta i kampovi s idejom da budu dostupni svim društvenim slojevima, ali ona baš i nije zaživjela u stvarnosti. Iako se u prvim godinama nakon rata propagirala ideja da su svi smještajni kapaciteti dostupni svima, svi hoteli i odmarališta ipak nisu bili dostupni svim slojevima „proletarijata”. Kako je država sve više bila zainteresirana za priljev deviznih sredstava, ideja o „odmoru proletarijata” polako je padala u zaborav i ostavljena povijesti.

\section{Zaključak}

Nakon Drugoga svjetskog rata na globalnoj razini promijenjen je odnos prema turizmu (prvenstveno zbog mogućnosti primjene novih tehničko-tehnoloških rješenja i pojave viška slobodnoga vremena), pa tako i u Hrvatskoj i Jugoslaviji. S obzirom na to da su nakon završetka rata u novoj socijalističkoj Jugoslaviji i Hrvatskoj korjenito promijenjeni uvjeti za razvoj turizma i prostornoga planiranja (zakonski okviri djelovanja, vlasništvo, društveni planovi razvoja itd.), u prvo vrijeme turizam se događao stihijski jer nije bio predmet koordiniranih društveno-ekonomskih i prostornih planova.

Kako je turizam nakon Drugoga svjetskog rata nezaustavljivo prodirao na cijelu jugoslavensku obalu, zbog interesa za priljev deviza od inozemnoga turizma sve više je dobivao na političko-gospodarskom značenju te je uvršten među prioritetne ciljeve gospodarskoga razvoja. Stoga je razvoj turizma bio potaknut brojnim mjerama investicijskih politika. Njima su stvorene pretpostavke za gradnju tehničke infrastrukture i nove turističke arhitekture - hotela, čime su stvarani uvjeti za konkurentnost inozemnom turističkom tržištu. Takve mjere bile su posebno važne za ostvarenje pozitivnih deviznih efekata. Sve pozitivne rezultate turizma vlast je pripisivala dobroj provedbi politike i kvalitetnim planovima.

75 STANKOVIĆ, Turizam u Jugoslaviji, 148. U Jugoslaviji je 1960. u hotelima bilo 30.879 ležajeva (12,1\%), a u domaćinstvima 82.591 (32,3\%). Već 1970. u hotelima je 119.534 (17,1\%), a u domaćinstvima 202.740 ležajeva (29,2\%).

76 KULIĆ, „East? West? Or Both? Foreign perceptions of architecture in Socialist Yugoslavia”, 87-105. 
Novi pristup turizmu najviše je bio vidljiv u uspostavi nove mreže organizacija i institucija za planiranje turizma, osnivanju društvenih turističkih poduzeća te sagledavanju turizma u širem razvojnom i prostornom kontekstu, a ne samo kroz pojedinačne investicije. Novi pristup u prostornom planiranju turizma najvidljiviji je u osmišljenoj stručnoj metodologiji izrade prostornih planova te realiziranju novooblikovane hotelske arhitekture. Obrazloženja arhitekata za izgradnju nove, skupe, atraktivne i kvalitetne hotelske arhitekture često su bila potkrijepljena time da je ona potrebna jer odražava novo socijalističko društvo i suvremene trendove. Stoga su ideje arhitekata u vrijeme socijalizma vezane za realizaciju bile u nešto povoljnijem položaju nego onih u kapitalističkim zemljama, čije su zamisli morale biti ekonomski opravdane. Nesumnjivo, intenzivna i kvalitetno oblikovana hotelska izgradnja ne bi se mogla realizirati u tolikom broju i tako kratkom vremenu da nije bilo društveno-ekonomskoga interesa politike, koliko-toliko usklađenoga rada tijela i institucija, ali i koliko-toliko usklađenih planova razvoja.

Iako je novi model planiranja razvoja turizma trebao ponuditi uravnotežen razvoj na razini cijele države i republika, zbog velikih socijalnih te kulturoloških razlika na saveznoj razini to se nije dogodilo. Hrvatski Jadran zbog svoje atraktivnosti i duže tradicije bavljenja turizmom doživio je pravu ekonomsku, društvenu, kulturnu i prostornu transformaciju i na razini naselja ${ }^{77}$ i na razini regija. Ideja o turizmu koji bi omogućio jednake uvjete smještaja za sve slojeve društva ubrzo je zaboravljena jer je dana prednost deviznom priljevu.

Istražujući međuodnos turističkoga i prostornoga planiranja u Hrvatskoj i Jugoslaviji nakon Drugoga svjetskog rata (na temelju tadašnjega društveno-političkog sustava, sustava društvenoga planiranja, politike prema turizmu i prostoru, tijela uprave, specijaliziranih institucija za planiranje, stručnih udruženja, djelovanja političkih tijela, turističkoga prometa, prostornih planova turizma te intenziteta hotelske izgradnje), može se zaključiti da je 1960ih u znatnoj mjeri bio usklađen. Turistički i prostorni planovi nisu rađeni s ciljem podilaženja „sitnim” interesima lokalnih političkih elita ili investitora, nego vođeni logikom društveno usmjerenoga razvoja te raspodjele ulaganja na više razina.

S obzirom na to da je Hrvatska imala najdužu obalu u tadašnjoj Jugoslaviji, najdužu tradiciju bavljenja turizmom te da je bila perjanica među republikama u projekcijama razvoja turizma i prostornom planiranju turizma (zbog osmišljene metodologije izrade planova), za njezinu obalu izrađeno je najviše prostornih planova turizma (na više razina). To je rezultiralo intenzivnom i najbrojnijom hotelskom izgradnjom u Jugoslaviji. Povećanje broja ležajeva u hotelima bilo je posebno važno za razvoj inozemnoga turizma, a povećanje u radničkim i omladinskim odmaralištima bilo je važno za razvoj domaćega

77 Pojedina naselja prostorno su pomoću turizma i turističke arhitekture transformirana u prepoznatljiva moderna turistička odredišta XX. stoljeća, iako su negdje površine hotelskih naselja često bile veće od postojećih tradicijskih naselja. 
turizma. U dva i pol desetljeća nakon Drugoga svjetskog rata u Hrvatskoj i Jugoslaviji, osim što je znatno povećan broj ležajeva, bitno je promijenjena struktura broja ležajeva prema vrsti zgrada ugostiteljsko-turističke namjene, kao i kvaliteta. Premda je uvelike povećan broj ležajeva u hotelima, rastao je i njihov broj u privatnim domaćinstvima, ali ne u tako velikom postotku.

Obala je imala prioritet u odnosu na kontinentalni dio, ali to ne znači da za taj prostor nisu rađeni planovi razvoja turizma i prostorni planovi.

Iako su za prostorne planove i razvoj turizma uglavnom bili odgovorni arhitekti i ekonomisti, pogrešno bi bilo zaključiti da su u njima isticane samo ekonomske ili prostorne komponente razvoja. Ti su planovi u punom smislu imali interdisciplinarni pristup, a u njihovoj izradi intenzivno su sudjelovale različite struke. Ekonomska komponenta naglašavala je dinarski i devizni prihod, investicije, privlačenje inozemnih turista itd., a prostorno-arhitektonska komponenta isticala je odnos arhitekture i prostora ${ }^{78}$, kvalitetu izgradnje, moderno oblikovanje, kvalitetu tehničke infrastrukture i dr. Pritom se nameće pitanje realnosti i opravdanosti tako intenzivnoga planiranja razvoja turizma i hotelske izgradnje u društvenom vlasništvu, posebno s aspekta održavanja i osuvremenjivanja, što se kasnije i pokazalo.

Iako su 1960-e pokazivale kvalitetne pomake u pripremi i realizaciji planski osmišljenih područja ugostiteljsko-turističke namjene i turističke arhitekture, turistička urbanizacija imala je određene izazove jer je išla ispred svojega vremena. Planovi razvoja ponekad su izazivali otpor među lokalnim stanovništvom jer ono često nije bilo spremno za intenzivni razvoj turizma, tj. brze društvene promjene.

Domaća arhitektonska struka za vrijeme socijalizma, posebno ona u $\mathrm{Hr}$ vatskoj, nametnula se u oblikovanju turističkih odredišta te je uspješnim realizacijama zainteresirala ne samo domaće nego i inozemne turiste i stručnjake. Zanimljivo je da strani stručnjaci u ovome stoljeću pozitivno ocjenjuju prostorno planiranje turizma Hrvatske i Jugoslavije za vrijeme socijalizma jer smatraju da se međuodnos turizma i prostora nije sagledavao samo s ekonomskoga aspekta, nego su uvažavane i druge vrijednosti prostora.

Iako su Regionalni plan Južni Jadran (1968. - 1969.) i Koordinacioni regionalni prostorni plan Gornji Jadran (1970. - 1972.) smatrani vrlo kvalitetnim regionalnim planovima u Europi, zbog svoje složenosti i utjecaja brojnih nepredvidivih čimbenika većim su dijelom ostali nerealizirani. Ali njihova stručna metodologija izrade služila je kao podloga za izradu novih prostornih planova u Hrvatskoj sve do 1991.

U svakom slučaju, socijalno-ekonomska liberalizacija turizma sredinom 1960-ih s ideološkom pozadinom, novim tijelima provedbe, usvojenom metodološkom strukturom, interdisciplinarnim pristupom i pragmatičnim odnosom s lokalnom birokracijom i državnom politikom provela je novi model

78 Pritom se misli na odnos prema pomorskom dobru, postotku izgrađenosti čestice, postotku sadnih (zelenih) površina, osiguranje zabavnih i rekreativnih površina itd. 
društvenoga i prostornoga planiranja. Usvojena nova metodologija izrade planova željela je pomiriti sva proturječja između turizma, prostora i općega razvoja, a okarakterizirana je kao planiranje harmoniziranoga razvoja. To u stvarnosti nije bilo moguće provesti u cijelosti s obzirom na to da su se paralelno odvijali turbulentni i brojni socijalni modernizacijski procesi. Društveni planovi razvoja nisu mogli uzeti u obzir sve upravno-administrativne i reorganizacijske čimbenike, kao i dramatične događaje ukupnoga društveno-političkog i ekonomskog sustava koji su slijedili 90-ih godina. Ispravni metodološki koraci za kontinuirano i usklađeno planiranje sredinom 1960-ih unijeli su znatnije promjene u sustav turističkoga i prostornoga planiranja. S njihovom provedbom uvidjela se sva složenost planiranja zbog utjecaja sve većega broja nepredvidivih čimbenika. Provedba planova dodatno je usložnjena jer su oni često djelovali apstraktno i kontradiktorno u političkom sustavu koji je imao ograničenu sposobnost odgovoriti na pitanja ponekad utopijskih planova.

\section{Literatura}

„XIII kongres AIEST”. Turizam 10 (1962), br. 10-11: 2.

ALFIER, Dragutin. „Mjesto turizma u planovima prostornog uređenja”. Turizam 10 (1962), br. 4-5: 14-17.

ALFIER, Dragutin. „Sinteza suvremenog turizma - Glavne misli iz knjige Aspects du XX ${ }^{\mathrm{e}}$ siecle od A. Siegfrieda”. Turizam 4 (1956), br. 11: 24-26.

ALFIER, Dragutin; DOMANIK, Roman. „Osnovne pretpostavke o ekonomici i unapređenju našeg turizma”. U: Zbornik rasprava o problemima turističke privrede. Savjetovanje u Dubrovniku od 28. do 30. listopada 1954. Društva ekonomista Hrvatske, ur. L. Karli i M. Novak. Zagreb: Ekonomski pregled, 1955, 3-46.

ANDRIĆ, Neda i sur. „Regionalni aspekti planiranja turizma”. Turizam 10 (1962), br. 10-11: 18-26.

ANIĆ, Tomislav. „Normativni okvir podržavljenja imovine u Hrvatskoj/ Jugoslaviji 1944. - 1946." Časopis za suvremenu povijest 39 (2007), br. 1: 25-62.

ANIĆ, Tomislav; BRKOVIĆ, Vjera. „Akcijski planovi protiv nepismenosti u Hrvatskoj od 1945. do 1970-ih". Časopis za suvremenu povijest 52 (2020), br. 3: 705-729.

ANTOLIĆ, Vladimir. „Makarska Generalna regulatorna osnova”. Arhitektura 3 (1949), br. 18-22: 63-64.

BARBIĆ, Mate. „Osnovni ekonomski problemi sezonskog ugostiteljstva”. $\mathrm{U}$ : Zbornik rasprava o problemima turističke privrede. Savjetovanje u Dubrovniku od 28. do 30. listopada 1954. Društva ekonomista Hrvatske, ur. L. Karli i M. Novak. Zagreb: Ekonomski pregled, 1955, 47-72.

BEYER, Elke; HAGEMANN, Anke; ZINGANEL, Michael. Holidays after the Fall. Seaside Architecture and Urbanism in Bulgaria and Croatia. Berlin: Jovis, 2013. 
BOLTAR, Dragan. „Neki aspekti planiranja i opreme jadranske magistrale". Turizam 11 (1963), br. 4-5: 18-22.

BOLTAR, Dragan. „Prvi pokušaj prostornog planiranja turizma u nas”. Arhitektura 16 (1962), br. 15-18: 17-18.

DOMANIK, Roman. „Smjernice turističke politike 1963.” Turizam 11 (1963), br. 1: 1-2.

DOMANIK, Roman. „Turizam u društvenom planiranju razvitka NRH 1961". Turizam 9 (1961), br. 1-2: 2.

DOMANIK, Roman. „Utjecaj turizma na razvitak privrede turističkih područja”. Ekonomski pregled 5 (1954), br. 10: 595-606.

DUDA, Igor. "'Radim sve što treba'. Aktivisti u mjesnim zajednicama u Jugoslaviji 1970-ih i 1980-ih”. Časopis za suvremenu povijest 52 (2020), br. 3: 731-758.

DUDA, Igor. U potrazi za blagostanjem. O povijesti dokolice i potrošačkog društva u Hrvatskoj 1950-ih i 1960-ih. Zagreb: Srednja Europa, 2005.

DUMBOVIĆ BILUŠIĆ, Biserka; JAKAŠA BORIĆ, Viki; KRANJČEVIĆ, Jasenka. „Hotelski sklop otoka Veliki Brijun; Urbanističko arhitektonska geneza”. Prostor 23 (2015), br. 2 (50): 354-369.

ENSMINGER, Slavko. „Urbanizacija sela putem razvoja turizma”. Turizam 18 (1970), br. 5: 10-12.

FRANIĆ, Milivoj. Razvoj turizma u Makarskoj. Makarska: Turistička zajednica grada Makarske, 2006.

FRANKOVIĆ, Eugen. „Urbanizam na Jadranu danas”. Život umjetnosti 5 (1967), br. 5: 42-47.

GAŠPAROVIĆ, Franjo. „Dosadašnji napori za prostorno planiranje jadranskog područja”. Turizam 11 (1963), br. 4-5: 5-6.

GAŠPAROVIĆ, Franjo. „O dosadašnjoj turističkoj izgradnji Jadranske obale”. Čovjek i prostor 13 (1966), br. 160-161: 1-7.

GAŠPAROVIĆ, Franjo. „Problemi prostornog planiranja turističkih područja”. Ekonomski pregled 20 (1969), br. 3-5: 382-403.

GAŠPAROVIĆ, Franjo. „Regionalno prostorno planiranje Jadranskog područja”. Arhitektura 14 (1960), br. 4-6: 73-74.

GAŠPAROVIĆ, Franjo; ŠALAT, Damir. „Osnovna razmatranja u planiranju razvoja turističkih područja. Primjer - Projekt Južni Jadran”. Ekonomski pregled 22 (1971), br. 12: 728-747.

GRANDITS, Hannes; TAYLOR, Karin. Yugoslavia's Sunny Side: A History of Tourism in Socialism (1950s-1980s). Budapest; New York: Central European University Press, 2010.

HOLJEVAC TUKOVIĆ, Ana. „Društveno-gospodarske reforme 1950 1952. i njihov odraz na upravu Narodne Republike Hrvatske”. Arhivski vjesnik 46 (2003), br. 1: 131-146. 
KOBAŠIĆ, Antun. Turizam u Jugoslaviji: razvoj, stanje i perspektive. Zagreb: Informator, 1987.

Koordinacioni regionalni prostorni plan Gornji Jadran. Zagreb: Urbanistički institut SR Hrvatske, 1972.

KRANJČEVIĆ, Jasenka. „Abandoned Tourism Resorts in Croatia: The consequences of discordant spatial planning and tourism development policies". U: Evolution of Destination Planning and Strategy: The Rise of Tourism in Croatia, ur. Larry Dwayer, Renata Tomljenović i Sanda Čorak. New York; London: Palgrave Macmillan, 2016, 173-200.

KRANJČEVIĆ, Jasenka. „Promet i turizam u prostornim planovima na području Hrvatskog zagorja 1958. i 1963.” U: Promet i turizam. Zbornik radova 1. simpozija Veleučilišta Hrvatsko zagorje, Krapina, Tuheljske Toplice od 25. do 27. travnja 2013., ur. Mira Hercigonja-Szekeres, Antun Presečki i Nenad Sikirica. Krapina: Veleučilište Hrvatsko zagorje, 2013, 3-7.

KRANJČEVIĆ. Jasenka. „Regeneracija (napuštenih) turističkih zona”. U: Strategije urbane regeneracije, ur. Ariana Korlaet. Zagreb: Hrvatski zavod za prostorni razvoj, 2016, 108-115.

KRANJČEVIĆ, Jasenka. „Turizam u prostornim planovima Makarskog primorja od 1945. - 1990." U: Makarsko primorje danas. Makarsko primorje od kraja Drugog svjetskog rata do 2011., ur. Marko Mustapić i Ivan Hrstić. Zagreb: Institut društvenih znanosti Ivo Pilar, 2012, 211-230.

KRANJČEVIĆ, Jasenka. Zanemarena baština. Prostorne strukture sela u Hrvatskoj. Zagreb: Srednja Europa, 2018.

KRANJČEVIĆ, Jasenka; HAJDINJAK, Sanja. „Tourism Urbanization in Croatia: The Cases of Poreč in Istria and Makarska in Dalmatia". Südost-Europa 67 (2019), br. 3: 393-420.

KRANJČEVIĆ, Jasenka; STOBER, Dina. „Potreba inventarizacije napuštenih izgrađenih područja - nužnost za planiranje turizma u kontinentalnoj Hrvatskoj". U: EU i hrvatsko graditeljstvo. Zbornik radova. Sabor hrvatskih graditelja, 17.-19. listopada 2016., Cavtat, ur. Stjepan Lakušić. Zagreb: Hrvatski savez građevinskih inženjera, 2016, 263-273.

KRAPF, Kurt. „Turizam faktor moderne privrede”. Turizam 10 (1962), br. 10-11: 3-5.

KULIĆ, Vladimir. „East? West? Or Both? Foreign perceptions of architecture in Socialist Yugoslavia”. Journal of Architecture (RIBA) 14 (2009), br. 1: 87-105.

MARASOVIĆ, Miro. „O dosadašnjoj turističkoj izgradnji jadranske obale". Čovjek i prostor 13 (1966), br. 160-161: 1-9.

MARINOVIĆ-UZELAC, Ante. Naselja, gradovi, prostori. Zagreb: Tehnička knjiga, 1986.

MATOŠIĆ, Joe, ur. Ilustrirani privredni turistički i hotelski vodič po Jugoslaviji. Zagreb, 1966. 
Metodologija i uputstva za izradu dugoročnog programa razvitka turizma. A) Primorska turistička područja. Zagreb: Komisija za turizam Odbora za privredu Izvršnog vijeća Sabora NR Hrvatske, 1959.

MIHLETIĆ, Ante. „Turizam i planiranje poljoprivrede u jadranskom području”. Turizam 11 (1962), br. 4-5: 14-17.

MILIĆ, Bruno. „Izrada prostornih planova za turistička područja”. Turizam 11 (1963), br. 4-5: 10-13.

„Nekoliko tipova zadružnih domova iz NRH“. Arhitektura 2 (1948), br. 7: 15-18.

„Perspektive privrednog razvoja i turizam”. Turizam 8 (1960), br. 6: 1-2.

PETROVIĆ, Branko; ŽULJIĆ, Stanko. Metodologija regionalnog planiranja. Zagreb: Urbanistički institut NR Hrvatske, 1956.

„Predsjednik Tito o turizmu”. Turizam 10 (1962), br. 8: 1.

PRELOG, Milan. Prostor - vrijeme. Zagreb: Društvo historičara umjetnosti, 1973.

Program dugoročnog razvoja i plan prostornog uređenja jadranskog područja. Zagreb: Urbanistički institut SR Hrvatske, 1967.

Programska skica za izradu urbanističkog plana Kumrovec. Zagreb: Urbanistički institut NR Hrvatske, 1954.

„Razvoju turizma moramo posvetiti još veću pažnju - iz referata Josipa Broza Tita na devetom kongresu Saveza komunista Jugoslavije”. Turizam 16 (1969), br. 4-5: 1.

Regionalni plan Južnog Jadrana. UNDP i Vlada SFRJ, 1968-1969.

Regionalni prostorni plan Istre. Zagreb: Urbanistički institut SR Hrvatske, 1969.

SEISSEL, Josip. „Aktuelno stanje izgradnje na jadranskom području”. Turizam 11 (1963), br. 4-5: 2-3.

STANKOVIĆ, Stevan M. Turizam u Jugoslaviji. Beograd: Turistička štampa, ${ }^{3} 1990$.

Statistički ljetopis Hrvatske. Zagreb: Državni zavod za statistiku, 2008.

ŠEGVIĆ, Neven. Novi putovi graditeljstva. Split: vlastita naklada, 1945.

ŠEGVIĆ, Neven. „Za industrijalizaciju graditeljstva”. Slobodna Dalmacija (Split), 11. 7. 1945., 11.

ŠEGVIĆ, Neven. „Zemaljsko gradjevno-projektantski zavod Hrvatske odigrat će značajnu ulogu u obnovi i izgradnji zemlje i stvaranju naše nove arhitekture". Vjesnik (Zagreb), 4. 2. 1946., 3.

ŠEVČIK, Boris. „Planiranje i projektiranje zaštićenih prostora i objekata jadranskog područja”. Turizam 11 (1963), br. 4-5: 17-18.

„Treba mijenjati politiku u turizmu”. Turizam 10 (1962), br. 10-11: 1.

Tržišni aspekti i raspored turističke potražnje kao podloga za turističku rajonizaciju Jadranskog područja. Zagreb: Zavod za ekonomiku turizma, 1965. 
Turistički savez Hrvatske u trideset godina. Zagreb: Turistički savez Hrvatske, 1983.

„Turizam na jesenjem ZV”. Turizam 9 (1961), br. 10-11: 14-16.

„Turizam veoma važna privredna grada, riječi predsjednika Tita”. Turizam 13 (1965), br. 10: 1.

UGRENOVIĆ, Vladimir. „Životni zadaci arhitekture i problemi naše tehničke nastave". Narodni list 2 (1946), br. 242: 7.

Urbanistički institut SR Hrvatske 1947-1987. Zagreb: Urbanistički institut SR Hrvatske, 1987.

Veliki geografski atlas Jugoslavije. Zagreb: Sveučilišna naklada Liber, 1987.

„Zakon o petogodišnjem planu. Razvitak narodne privrede FNRJ 19471952." Službeni list Federativne Narodne Republike Jugoslavije (Beograd), 1947.

ŽULJIĆ, Stanko. Prostorno planiranje i prostorna istraživanja - odabrani napisi. Zagreb: Ekonomski institut Zagreb, 1983. 


\section{SUMMARY}

\section{Touristic and Spatial Planning in Croatia and Yugoslavia in the 1960s}

Based on the contemporaneous and recent (domestic and foreign) literature and spatial plans, this paper examines the relationship between touristic and spatial planning in Croatia and Yugoslavia in the 1960s. The relationship is determined using the analytical-interpretative method of the then socio-political system, tourism and spatial policy, social planning, administrative bodies, institutions specialised for planning, tourist traffic, produced spatial plans, the intensity of building accommodation capacity, etc. In the first period after the end of the war, tourism developed in an uncontrolled manner because it was not the subject of coordinated socio-economic and spatial plans. Due to a growing interest for the inflow of foreign currencies from foreign tourists, tourism gradually gained significance and was regularly given priority in development plans.

The new approach to spatial planning was most visible in the developed methodology of spatial plan production and the hotel architecture and constructed hotel complexes. Since the Croatian coast had the longest Adriatic shoreline in the then Yugoslavia, the longest tradition of tourism, and was the flagship among the republics in tourism development projections and the spatial planning of tourism (because of the developed methodology of plan production), the largest number of touristic spatial plans during the socialist period were made for the Croatian Adriatic coast (on multiple levels), and the greatest investments were made in building hotel capacity there. Despite the initial idea of developing tourism and equal accommodation options for all, the new tourism planning model transformed away from this basic idea and gave priority to exponential economic growth. This new approach to tourism was most visible through the establishment of a new network of organisations and institutions for planning tourism and tourism planning in a broader spatial context rather than only on the level of individual investments.

All factors regarding the implementation of social plans could not have been taken into account because all the administrative and reorganisation factors as well as the dramatic events of the socio-political and economic system as a whole that took place in the 1990 s could not have been predicted. The proper methodological steps for continued and coordinated planning in the 1960s introduced significant changes into the system of touristic and spatial planning. After the implementation of the plans began, the complexities of planning (numerous unpredictable factors) that influenced their realisation became apparent. The practice of planning was further complicated because plans often acted in an abstract and contradictory manner in a political system that had a limited capacity for realising quality — and in some cases utopian-plans.

Key words: touristic planning; spatial planning of tourism; history of spatial planning and tourism; 1960s; Croatia; Yugoslavia 